\title{
Proceedings of the lowa Academy of Science
}

1935

\section{A Study of Individualized Instruction at the College Level}

Daniel D. Feder

University of lowa

Let us know how access to this document benefits you

Copyright @1935 lowa Academy of Science, Inc.

Follow this and additional works at: https://scholarworks.uni.edu/pias

\section{Recommended Citation}

Feder, Daniel D. (1935) "A Study of Individualized Instruction at the College Level," Proceedings of the lowa Academy of Science, 42(1), 159-166.

Available at: https://scholarworks.uni.edu/pias/vol42/iss1/75

This Research is brought to you for free and open access by the lowa Academy of Science at UNI ScholarWorks. It has been accepted for inclusion in Proceedings of the lowa Academy of Science by an authorized editor of UNI ScholarWorks. For more information, please contact scholarworks@uni.edu. 
Feder: A Study of Individualized Instruction at the College Level

\title{
A STUDY OF INDIVIDUALIZED INSTRUCTION AT THE COLLEGE LEVEL
}

\author{
DANIER, D. FEDER
}

With a philosophy that makes paramount the greatest possible growth for each individual student as the background, the Department of French at the University of Iowa has conceived and put into operation a plan of individualized instruction. This plan, in effect since September, 1933, marks the latest development of a comprehensive experimental program which has had continuous growth during the past ten years.

To provide for the special needs of the individual student every possible means must be taken of diagnosing his innate abilities and the effect of his previous educational experiences through aptitude and placement examinations administered by the university and by the department.

The syllabus of the course constitutes the contract which the student undertakes to execute in entering upon the course. Beginning with a broadly outlined description of the work to be covered and culninating in a series of highly specific projects, developed in detail, it is the student's guide and manual until the goal set for the semester has been reached.

Few students, especially superior ones, find it pleasant or even possible to work on the dead level which is inevitable in any well planned class aining at steady advance. Under the individualized plan students may have wide latitude in determining the procedure best suited to their individual needs, preferences, or living conditions, with the realization, however, that the responsibility for completing the work on time rests solely with them. The student who needs more than the normal amount of time, in order to do acceptable work, suffers no penalties or handicaps.

With the definition of standards, based on the principle of mastery, there comes a reinterpretation of the meaning of a passing grade. In terms of the performance of preceding classes a department can readily determine the minimum quality and quantity of work which will give the student the requisite minimum essentials.

The philosophy of individualized instruction makes the classroom the logical center of learning and gives it increased importance of function. Besides functioning as a center to which the student may report for checking on his progress, for special drill 
and remedial work, for consultation with the instructor, the classroom provides the surroundings for his social development. In the system of individualized teaching the classroom is the discovery ground for the student.

Students are sectioned on the basis of ability because of the administrative and instructional merits which such grouping offers. It permits the assigning of instructors to classes for which they are best fitted. It facilitates the teacher's problems, because with homogeneity of ability there is a relative homogeneity of pace and level of work, so that instructors are not required to have constantly available so wide a range of detailed information and test materials.

To maintain objective standards of performance, to measure and evaluate achievement fairly, and to permit diagnosis and prescription, carefully constructed objective examinations must be an integral part of individualized instruction. These tests are of three major types:

1. Every stage of the work is checked by short daily or project tests covering the specific material of the project. The students correct these themselves and move forward only when they have achieved a practical mastery, almost perfection. Since the sole record of these tests is kept by the student himself, no grades being given, there is not the slightest incentive to dishonesty.

2. When the student feels that he has mastered a stated group of projects which constitute a natural or convenient unit he takes an individual unit test covering the material of these projects. These tests are scored by the department staff. Scores are recorded, and grades are given, chiefly because of student curiosity. Should a student receive a grade lower than $\mathrm{C}$ he must review, using his daily tests to detect weak points, and then take a retest. This practice parallels the mastery technique for the short projects.

3. Whenever the student reaches the goal set for the end of the semester he may take the final examination and move ahead. In this plan final examinations are taken as inclividual unit tests, but they are more comprehensive and serve to review and integrate the course for the student.

\section{THE EXPERIMENTAI, ResUi,TS}

'The class of 1932-33 was taken as the control group. Comparisons in terms of eleven major tests were made between the experimental group, the 1933-34 class, and the control group. Although the original experimental group showed a slight superiority in some of the ability measures, in the final evaluation the two groups were 
Feder: A Study of Individualized Instruction at the College Level

$1935]$ STUDY OF INDIVIDUALIZED INSTRUCTION

matched on the basis of the Foreign Language Aptitude test. Table I shows the comparability of the two groups in terms of the matching criterion.

Table I - Comparability of control and experimental groups in terms of the Foreign Language Aptitude test

\begin{tabular}{l|c|c|c}
\hline \multicolumn{1}{c|}{ Group } & MEAN & SD & N \\
\hline Control & 83.2 & 23.1 & 190 \\
Experimental & 83.0 & 23.1 & 268 \\
\hline
\end{tabular}

In Table II is presented the comparative performance of the experimental and control groups on the eleven crucial tests. The experimental group excelled the control in all but one, a second semester test. Four of the six differences in first semester and one in second semester are statistically significant. The direction of all but one of the other differences supports the belief that a reliable

Table II-Differences in Achiciement and Variability During First and Second Semesters for the Control and Experimental Groups

\begin{tabular}{|c|c|c|c|c|c|c|c|c|}
\hline Test & GROUP & MEAN & $\mathrm{SD}$ & $\mathrm{M}_{1}-\mathrm{M}_{2}$ & $\frac{\text { D }}{\text { Diff. }}$ & $\mathrm{SD}_{1}-\mathrm{SD}_{2}$ & $\frac{D^{*}}{\text { Diff. }}$ & $\mathrm{N}$ \\
\hline 1 & 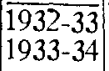 & $\begin{array}{l}34.10 \\
38.09\end{array}$ & $\begin{array}{l}7.74 \\
5.22\end{array}$ & -3.99 & -7.98 & 2.52 & 5.60 & $\begin{array}{l}192 \\
266\end{array}$ \\
\hline 2 & $\mid \begin{array}{l}1932-33 \\
1933-34\end{array}$ & $\begin{array}{l}42.25 \\
45.43\end{array}$ & $\begin{array}{l}8.31 \\
8.28\end{array}$ & -3.18 & -4.82 & .03 & .05 & $\begin{array}{l}191 \\
254\end{array}$ \\
\hline 3 & \begin{tabular}{|l|}
$1932-33$ \\
$1933-34$
\end{tabular} & $\begin{array}{l}35.52 \\
38.04\end{array}$ & $\begin{array}{l}8.01 \\
7.41\end{array}$ & -2.52 & -4.50 & .60 & 1.15 & $\begin{array}{l}189 \\
266\end{array}$ \\
\hline 4 & \begin{tabular}{|}
$1932-33$ \\
$1933-34$
\end{tabular} \mid & $\begin{array}{l}40.38 \\
48.34\end{array}$ & $\begin{array}{l}15.04 \\
12.92\end{array}$ & -7.96 & -7.44 & 2.12 & 2.16 & $\begin{array}{l}189 \\
226\end{array}$ \\
\hline 5 & $\begin{array}{l}1932-33 \\
1933-34\end{array}$ & $\begin{array}{l}32.65 \\
33.94\end{array}$ & $\begin{array}{l}8.88 \\
9.36\end{array}$ & -1.29 & -1.90 & -.48 & -.75 & $\begin{array}{l}181 \\
241\end{array}$ \\
\hline 6 & $\begin{array}{r}1932-33 \\
1933-34\end{array}$ & $\begin{array}{l}79.45 \\
80.55\end{array}$ & $\begin{array}{l}15.00 \\
17.05\end{array}$ & -1.10 & -.92 & -2.05 & -1.81 & $\begin{array}{l}171 \\
233\end{array}$ \\
\hline 7 & $\begin{array}{l}1932-33 \\
1933-34\end{array}$ & $\begin{array}{l}38.75 \\
42.11\end{array}$ & $\begin{array}{l}12.87 \\
11.07\end{array}$ & -3.36 & -3.08 & 1.80 & 1.96 & $\begin{array}{l}149 \\
207\end{array}$ \\
\hline 8 & $\left|\begin{array}{r}1932-33 \\
1933-34\end{array}\right|$ & $\begin{array}{l}31.97 \\
33.20\end{array}$ & $\begin{array}{r}10.35 \\
8.67\end{array}$ & -1.23 & -1.38 & 1.68 & 2.43 & $\begin{array}{l}150 \\
189\end{array}$ \\
\hline 9 & $\left|\begin{array}{|}1932-33 \\
1933-34\end{array}\right|$ & $\begin{array}{l}44.90 \\
43.79\end{array}$ & $\begin{array}{l}9.87 \\
9.09\end{array}$ & 1.11 & 1.23 & .78 & 1.03 & $\begin{array}{l}148 \\
167\end{array}$ \\
\hline 10 & $\left|\begin{array}{r}1932-33 \\
1933-34\end{array}\right|$ & $\begin{array}{l}50.82 \\
51.84\end{array}$ & $\begin{array}{r}10.17 \\
8.79\end{array}$ & -1.02 & -1.09 & 1.38 & 1.84 & $\begin{array}{l}149 \\
173\end{array}$ \\
\hline 11 & $\left|\begin{array}{c}1932-33 \\
1933-34\end{array}\right|$ & $\begin{array}{l}72.40 \\
75.70\end{array}$ & $\begin{array}{l}17.35 \\
17.00\end{array}$ & -3.30 & -2.04 & .35 & .26 & $\begin{array}{l}149 \\
166 \\
\end{array}$ \\
\hline
\end{tabular}
1. $32-\mathrm{I}-\mathrm{Voc}-\mathrm{A} 2$
2. 32-I-Pro-A3
3. 32-I-Com-A5
4. 32-I-Voc-B6
5. 32-I- Com- B7
9. 33-II-Com-B7
6. 32-I-Final
10. 33-II-Pro-A3
11. 33-II-Final

* The Lindquist-Wilks formula for the $\mathrm{SD}_{\mathrm{di} f \mathrm{l}}$ between means of "matched" groups was used here. It is described in the Journal of Educational Psychology for March, 1931. 
difference exists between the two groups as a result of the modified instruction.

Inspection of the standard deviations reveals that in all but two of the critical tests the experimental group showed less variability than did the control group. This may be interpreted as a direct result of the method of individualized instruction which required a minimum mastery level on each day's work. Under the traditional system of instruction, with more chance to do poor work, the group shows greater variability.

The improved performance is portrayed in a series of diagrams in which the frequency polygons for the two years are compared. The better performance is to be seen in a general upward shift throughout the entire area of the frequency polygons. In some cases skewed curves have resulted where symmetrical ones existed before.

In diagram I the blank bars labelled "1933" indicate the status of the experimental group with reference to grades earned by the end of the first semester. The stippled areas indicate the final disposition of the group with reference to first semester grades. Similarly the other bars indicate the status of the control and current groups.

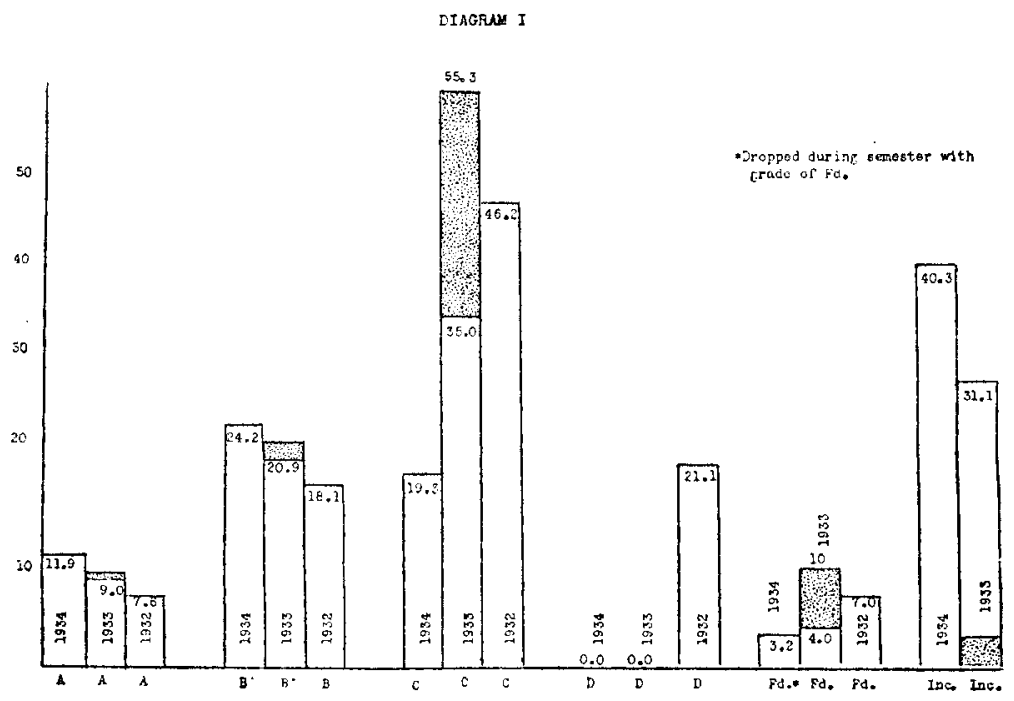

The data are expressed in percentages to facilitate comparison, and again it is apparent that the experimental group has exceeded the control in actual achievement. Even at the end of the first semester a higher percentage of A grades was assigned on the same basis as those given the control group than in the previous year. This is likewise true of the B grades. The drop in number of 
$\mathrm{C}$ grades was balanced by the large number of Incompletes in the extreme right hand column.

By the end of the second semester, however, the picture was considerably changed. A few more A's were achieved by students who were inclined to be somewhat slow in their method of working but who were nevertheless of high ability. These students simply chose to take an additional week or two of preparation. They did not need the entire second semester. This is true also of the few people who received the grade of $\mathrm{B}$ after the end of the regular session. However, for that considerable group of students, approximately $23 \%$, who received the grade of $\mathrm{C}$, several interesting characteristics are to be noted. The majority of these finished the semester's work in less than a month's additional time. There were a few who found it necessary to take the entire second semester in order to complete the first semester's work in an acceptable manner. Under the traditional system these students would have been completely lost. They would have failed French, not only in their first attempt but also in their second, and perhaps would have taken it a third time, finally passing the course on the basis either of sheer memory or due to kind offices of a weary instructor. None of these people who found it necessary to take two semesters in order to complete one semester's work achieved above a $\mathrm{C}$ grade. However, their tested performance indicates that they have achieved a fairly adlequate command of reading ability in French although they admittedly will never have that degree of proficiency attained by those students who received a $\mathrm{C}$ in the normal amount of time.

To summarize the data in diagram $\mathrm{I}$ it may be saicl that under the new plan there are more high grades; also there are more failures and incompletes. These latter two groups, however, claim only $10 \%$ of the entire group as compared with $28.1 \%$ of the control group who received grades of $D$ and $F d$. The difference of $18.1 \%$ is distributed in grades representing satisfactory achievement.

One might assume from this evidence that a student might, if he were so inclined, take two semesters in order to do one semester's work and thereby receive a better grade. The facts do not support such an assumption. Instead they indicate that each indiviclual can find his best working pace and chooses to work at that pace when he is given the liberty of making such a choice. At that pace he will do the best work of which he is capable. If he slows down his work will suffer, due to forgetting and ineffcient study habits. If he works too fast his work will suffer from carelessness and neglect. 
The scores of the 36 students who finished the year's work in much less than the normal time were plotted and superimposed on the general curves. In every case they fell exclusively in the two or three highest class intervals, in several instances completely dominating the high score intervals. Therefore, it may be concluded that these students were not sacrificing accuracy or efficiency for speed, but that their speed is a characteristic of their efficiency in learning.

Analysis of the prediction coefficients in Table III reveals that in all but two instances the coefficients for the experimental group were lowered. Although none of these differences has complete statistical significance, the fact that the figures are based on matched groups lends to their reliability.

Table III - Prediction Coefficients for the Experimental and Control Groups

\begin{tabular}{|c|c|c|c|c|c|c|}
\hline Year & $\begin{array}{l}\text { Coeffi- } \\
\text { cient }\end{array}$ & $r$ & $P E_{r}$ & Diff & $P E_{d i f f}$ & $\frac{\mathrm{D}}{\mathrm{PE}_{\mathrm{diff}}}$ \\
\hline $\begin{array}{l}1932 \\
1933\end{array}$ & $\Gamma_{12}$ & $\begin{array}{l}.62 \\
.64\end{array}$ & $\begin{array}{l}.04 \\
.03\end{array}$ & -.018 & .049 & .46 \\
\hline $\begin{array}{l}1932 \\
1933\end{array}$ & $r_{13}$ & $\begin{array}{l}.56 \\
.45\end{array}$ & $\begin{array}{l}.04 \\
.05\end{array}$ & -.111 & .067 & -1.65 \\
\hline $\begin{array}{l}1932 \\
1933\end{array}$ & $r_{14}$ & $\begin{array}{l}.67 \\
.63\end{array}$ & $\begin{array}{l}.04 \\
.03\end{array}$ & -.038 & .047 & -.81 \\
\hline $\begin{array}{l}1932 \\
1933\end{array}$ & $r_{15}$ & $\begin{array}{l}.62 \\
.46\end{array}$ & $\begin{array}{l}.04 \\
.05\end{array}$ & -.158 & .064 & -2.48 \\
\hline $\begin{array}{l}1932 \\
1933\end{array}$ & $r_{16}$ & $\begin{array}{l}.54 \\
.57\end{array}$ & $\begin{array}{l}.05 \\
.04\end{array}$ & .029 & .057 & .51 \\
\hline $\begin{array}{l}1932 \\
1933\end{array}$ & $r_{17}$ & $\begin{array}{l}.51 \\
.41\end{array}$ & $\begin{array}{l}.05 \\
.05\end{array}$ & -.099 & .071 & -1.41 \\
\hline $\begin{array}{l}1932 \\
1933\end{array}$ & $r_{18}$ & $\begin{array}{l}.71 \\
.62\end{array}$ & $\begin{array}{l}.03 \\
.03\end{array}$ & -.088 & .045 & -1.96 \\
\hline $\begin{array}{l}1932 \\
1933 \\
\end{array}$ & $r_{19}$ & $\begin{array}{l}.64 \\
.45 \\
\end{array}$ & $\begin{array}{l}.04 \\
.05 \\
\end{array}$ & -.192 & .063 & -.302 \\
\hline
\end{tabular}

1. Foreign Language Aptitude test

2. Total Vocabulary, Sem. I

3. Total Vocabulary, Sem. II

4. Total Comprehension, Sem. I 9. Total Composite Score, Sem. I

5. Total Comprehension, Sem. II

6. Total Pronunciation, Sem. I

7. Total Pronunciation, Sem. II

8. Total Composite Score, Sem. I

At first thought these drops in predictive efficiency were somewhat disconcerting. One wondered if the system of instruction would operate to invalidate any pre-instructional information concerning the student's ability and training. Inspection of the data yielded the fact that the correlations for the control group included those individuals who received grades of $D$ and $F d$. These low scores extended the range considerably beyond that of the experi- 
mental group. This coupled with the well known fact that the prediction of failure is the most reliable of all yielded a partial explanation.

In contrast with the traditional situation which would have found most, if not all, of the students of low language aptitude in the failure class, under the system of individualized instruction it became possible for them to produce acceptable work. By no means are all or even a large proportion of the students who needed additional time in which to complete the second semester's work recruited from the ranks of the lowest deciles. Some are students of excellent general ability; a few are poor college risks at best. However, by far the most significant fact revealed by this analysis was the unquestionably improved performance of the poorer students. Seen in this light the reduction in the predictive correlations for the experimental group is a source of satisfaction rather than of disappointment.

In studying the effects of individualized instruction it was assumed that the basic ability of an individual would exert a certain integrating influence upon the skills, and that, therefore, when each individual worked as best suited him, it might be expected that the

Table $I V$-Evaluation of the functional interrelationships of skills for the Control and Experintental Groups

\begin{tabular}{|c|c|c|c|c|c|c|c|}
\hline & Coefficient & Year & $r$ & $\mathrm{PE}_{\mathrm{r}}$ & Diff & $P E_{\text {dief }}$ & $\frac{\mathrm{D}}{\mathrm{PE}}$ \\
\hline 1 & $T_{12}$ & $\begin{array}{l}1932 \\
1933\end{array}$ & $\begin{array}{l}.66 \\
.69\end{array}$ & $\begin{array}{l}.04 \\
.03\end{array}$ & -.022 & .046 & -.46 \\
\hline 2 & $r_{13}$ & $\begin{array}{l}1932 \\
1933\end{array}$ & $\begin{array}{l}.55 \\
.64\end{array}$ & $\begin{array}{l}.04 \\
.03\end{array}$ & -.086 & .053 & -1.63 \\
\hline 3 & $r_{15}$ & $\begin{array}{l}1932 \\
1933\end{array}$ & $\begin{array}{l}.60 \\
.71\end{array}$ & $\begin{array}{l}.04 \\
.03\end{array}$ & -.118 & .048 & -2.47 \\
\hline 4 & $r_{24}$ & $\begin{array}{l}1932 \\
1933\end{array}$ & $\begin{array}{l}.61 \\
.52\end{array}$ & $\begin{array}{l}.03 \\
.05\end{array}$ & .080 & .061 & 1.31 \\
\hline 5 & $r_{34}$ & $\begin{array}{l}1932 \\
1933\end{array}$ & $\begin{array}{l}.81 \\
.76\end{array}$ & $\begin{array}{l}.02 \\
.03\end{array}$ & .027 & .055 & .49 \\
\hline 6 & $r_{35}$ & $\begin{array}{l}1932 \\
1933\end{array}$ & $\begin{array}{l}.79 \\
.84\end{array}$ & $\begin{array}{l}.02 \\
.02\end{array}$ & -.050 & .035 & -1.43 \\
\hline 7 & $\mathrm{r}_{20}$ & $\begin{array}{l}1932 \\
1933\end{array}$ & $\begin{array}{l}.63 \\
.61\end{array}$ & $\begin{array}{l}.04 \\
.04\end{array}$ & .049 & .028 & 1.77 \\
\hline 8 & $r_{40}$ & $\begin{array}{l}1932 \\
1933\end{array}$ & $\begin{array}{l}.81 \\
.77\end{array}$ & $\begin{array}{l}.02 \\
.03\end{array}$ & .041 & .034 & 1.21 \\
\hline 9 & $\mathbf{r}_{56}$ & $\begin{array}{l}1932 \\
1933 \\
\end{array}$ & $\begin{array}{l}.66 \\
.69 \\
\end{array}$ & $\begin{array}{l}.04 \\
.03 \\
\end{array}$ & -.025 & .049 & -.51 \\
\hline
\end{tabular}

1. Total Pronunciation, Sem. I 2. Total Pronunciation, Sem. II

Publishèd by Û NT ScholarWorks, 1935
4. Total Comprehension, Sem. II

5. Total Vocabulary, Sem. I

6. Total Vocabulary, Sem. II 
relationship between the skills would become even more marked. Table IV contains the intercorrelations between the various skills, and shows the significance of the obtained differences between the control and experimental groups.

For the first semester the degree of intercorrelation among the skills as measured by identical tests is quite strongly in favor of the experimental group. The negative differences obtained for the second semester relationships are due to the fact that the complete passing range of scores was not available, with the result that these correlations are based on a spuriously homogeneous group and are therefore spuriously low. This is to be noted also in the correlations between first and second semester performance in the same skills.

Although none of the differences is completely reliable, the consistency of their direction suggests that the system of individualized instruction, clemanding as it does a higher degree of mastery of each unit, results in a higher functional interrelationship of the various skills.

\section{SUMMARY}

The individualized method of instruction was designed to facilitate the learning of French of each student at his natural level of ability and his best rate of speed. The principles of individualized instruction comprised: (1) Recognition of the individual; (2) Outline of a course in its entirety; (3) Every student working at his best rate of speed and natural level of ability; (4) Minimum standards of achievement determined in terms of objective measures of satisfactory performance; (5) Recognition of partial achievement which the student can add to in subsequent semesters without the stigma of failure; (6) The responsibility for achievement on the individual student; (7) The classroom as laboratory and socializing agency; (2) Sectioning on the basis of ability; (9) Examinations as tools of instruction and self-evaluation.

Comparison with a matched control group indicates that achievement under the experimental system was superior to that under the usual classroom methods of instruction. Greater homogeneity in learning, with resultant lowering of prediction coefficients, was achieved by the experimental group. The functional interrelationship of the various skills involved in the reading of French was increased.

Department of Psychology,

UNIVERSITY OF IOWA, 